\title{
The impact of herbivorous insect on leaves of mangrove species Rhizophora stylosa and its relation to leaf nutrient level
}

\author{
INDAH TRISNAWATI", MUKHAMMAD MURYONO, ISKA DESMAWATI \\ Ecology Laboratory, Department of Biology, Faculty of Natural Sciences, Institut Teknologi Sepuluh Nopember. Gedung H Kampus ITS Sukolilo \\ Surabaya 60111, East Java, Indonesia. Tel./fax.: +62-31-5963857. `email: indahtris@ yahoo.com
}

Manuscript received: 7 February 2019. Revision accepted: 28 April 2019.

\begin{abstract}
Trisnawati I, Muryono M, Desmawati I. 2019. The impact of herbivorous insect on leaves of mangrove species Rhizophora stylosa and its relation to leaf nutrient level. Biodiversitas 20: 1409-1415. Intertidal mangrove ecosystem is a very unique ecosystem which is under threat due to anthropogenic disturbances like land conversion to promote paddy cultivation and aquaculture and pollution. Increased nutrient loading from human activities is expected to have stronger responses to both mangroves and their associated herbivores. This research is aimed to investigate vulnerability of mangroves caused by herbivory of herbivorous insects, focusing on the diversity and abundance of herbivorous insects, the level of mangrove leaf damage and its relation to nutrient levels within leaves in term of nitrogen, phosphorus, potassium and water content. We observed mangrove habitats located around Institut Teknologi Sepuluh November (ITS) Campus in Surabaya, East Java dominated by Rhizophora vegetation. Herbivorous insects showed individual abundance of $15.15 \%$ of the total insects found in mangroves around the studied areas. The area of relative leaf damage in Rhizophora stylosa leaves tended to be high in sapling habitus (11.96-24.56\%) compared to tree habitus $(6.97-16.71 \%)$. One way ANOVA showed non-significant difference in leaf area damaged between sapling and tree habitus $(\mathrm{F}=0.099, p-0.75)$, and percentage of herbivory between saplings and trees $(\mathrm{F}=0.0007, p-0.98)$. Concentrations of potassium $(\mathrm{K})$ was significantly higher in tree than sapling habitus, whereas leaf nutrient phosporous was significantly higher in sapling than tree habitus. Other leaf nutrients (total nitrogen and water) were relatively the same in both habitus. However, saplings contained more feeding deterrent tannins than trees. Leaf age is thought to be related to higher leaf palatability and insect herbivore nutrition in younger leaves, represented by sapling habitus.
\end{abstract}

Keywords: Herbivorous insects, mangroves susceptibility, nutrient level, Rhizophora stylosa

\section{INTRODUCTION}

Mangrove ecosystems are known to have very important ecological, socio-economic and social-cultural roles (Setyawan and Kusumo 2006). As one of coastal ecosystems, mangrove ecosystems are vital to stabilize environmental nutrient cycles as well as to support community's livelihoods. The ability of mangrove ecosystems to maintain these functions depends on supporting factors, including environmental quality and substrate conditions (Wantasen 2013). Yet, mangrove ecosystems have been damaged at an alarming rate. Over the past 50 years, about one-third of the world's mangrove forests have lost (Alongi 2002). It is estimated that mangroves in developing countries tend to decline by around 25 percent by 2025 (Ong and Khoon 2003). In Indonesia, which is a country with the largest mangrove forests in the world, the rate of mangrove loss is higher by 90\% in Java and Sumatra (Bengen and Dutton 2003).

The position of intertidal mangrove wetlands causes these habitats to be sensitive and vulnerable to climate change, although other factors will also have a strong influence on mangrove ecosystems. Besides threats due to the effects of global climate change, mangroves are also threatened by anthropogenic factors, such as agricultural and aquaculture activities. Disturbances caused by the effects of nutrient enrichment and climate change are known as the main threats occurring simultaneously to estuary and coastal regions throughout the world (Lloret et al. 2008; Turner et al. 2009; Feller et al. 2017).

The large intensity of rain and storms in the tropics can lead to increased runoff of materials to coastal wetlands, including nutrient inputs caused by human activities, such as agriculture and aquaculture (Turner et al. 2009). As a result, nitrogen $(\mathrm{N})$ and phosphorus $(\mathrm{P})$ increase, as well as the retention of carbon $(\mathrm{C})$, which can lead to differences in the important role of $\mathrm{N}$ and $\mathrm{P}$ in primary productivity and biotic interactions (Lovelock et al. 2009). The availability of nutrients can affect herbivore activities, nutrient dynamics, and the growth of mangroves which varies along tidal gradients and climates. The effect of nutrient enrichment on natural ecosystems is the stimulation of productivity as well as an increase in nutrient concentrations in plant tissues. It is suspected that there is correlation between vulnerability to herbivores and $\mathrm{N}$ content in tissues, which might be related to treatment of fertilizers (Feller et al. 2013). Onuf et al. (1977) examined the interactions between nutrients and herbivores in mangrove ecosystem and found that nutrient enrichment in mangroves causes high damages due to herbivore activities. The increasing damages are due to the increasing quality of plant tissue as a source of nutrition to herbivores.

Herbivory occurring in mangrove habitat is considered low compared to other tropical habitats, as well as the assumption that herbivorous animals do not play very important role in ecological systems of mangrove forests. 
Moreover, mangroves are only considered as a swamp habitat of mosquitoes and sandflies, and not the habitat of herbivorous insects (Burrows 2003). However, a study by Cannicci et al. (2008) reported that herbivores are to be able to change the structure and function of mangroves. Herbivory impacts on mangroves include the loss of presenescent leaves, damages and inhibition of new leaf production, changes in leaf quality and changes in the leaf fall time, which ultimately affect mangrove growth and survival (Burrows 2003).

Therefore, studies to evaluate biotic interactions between herbivorous insects and mangroves are required. This study is aimed to assess the diversity and composition of herbivorous insects at mangrove area around the campus of Institut Teknologi Sepuluh November (ITS) in Surabaya, East Java. This study also estimates the level of leaf damage, the percentage of herbivory, and leaf nutrient content. The further studies were carried out in the mangrove ecosystem managed by farmers around the ITS Campus Surabaya. The mangrove area around the ITS Campus Surabaya provides contextual example regarding the presence of nutrient enrichment activities, such as agriculture and aquaculture. Based on the results of vegetation analysis carried out at the mangrove area, Rhizophora stylosa was found as the most important mangrove species among others for each growth stage/category (unpublished data 2018). The results of this study can be used as important baseline information relating to the vulnerability status of mangroves to herbivory interaction.

\section{MATERIALS AND METHODS}

\section{Study site}

The research was carried out for three months from September to November 2018 in which data was collected once every two weeks. The research location was at mangrove ecosystem managed by farmers around the ITS Campus Surabaya with an area of \pm 0.5 ha (Figure 1).

\section{Procedures}

Assemblages of herbivorous insects

A sampling of insect as herbivores of Rhizophora stylosa at the ITS Campus mangrove area was conducted from September 2018 to November 2018. Every two week, morning survey of herbivores was carried out during the period of 07:00 am - 10:00 am on mangrove leaves of all trees in the plot of each site using sweep net (Insect Net long handled $100 \mathrm{~cm}, 50 \mathrm{~cm}$ diameter). Yellow pan trap method with diameter of $40 \mathrm{~cm}$ and height of $20 \mathrm{~cm}$ was set up as a trap for $24 \mathrm{hrs}$. Insects were placed in insect vials containing $75 \%$ of alcohol for soft and hard insects and in collection paper for the order of Lepidoptera and Heteroptera. The sweep net method was performed to quantitatively sample insects perching or flying around vegetation (Voshell Jr 2002). The yellow pan trap method was performed to collect flower-visiting insects, which are usually active in the morning and afternoon (Campbell and Hanula 2007).

\section{Measurement of herbivory: leaf damage level}

Observation on leaf damage in the field was done by observing the morphology of leaves directly according to the type of damage caused by insects following Green and Joe (1990); Labandeira et al. (2007); Grundy (2010).

Leaf damage was observed in two categories of growth stage (habitus), i.e. saplings, and trees with diameter of $3.5 \mathrm{~cm}$ and $10 \mathrm{~cm}$, respectively (BSN 2011). Three mangroves per plot were randomly selected at each sampling occasion. The observation was done on three upper branches of each individual tree. Leaves were sampled monthly for eight months to estimate the leaf area consumed by herbivores following discrete sampling method although this method tends to under-estimate herbivory impact (Burrows 2003) as it ignores impacts on leaf longevity.
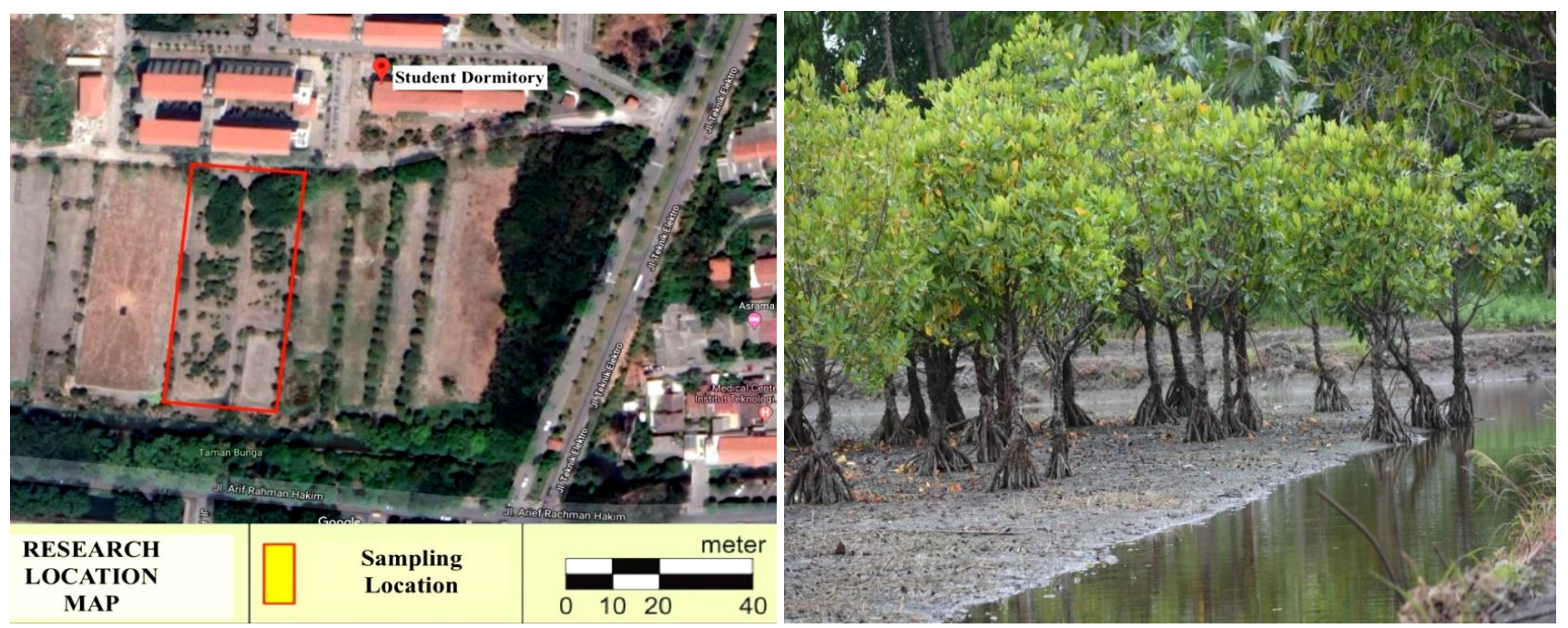

Figure 1. Location of research at mangrove ecosystem managed by farmers around the ITS Campus, Surabaya, Indonesia (Modified from www.googleearth.com) and mangrove landscape at ITS Campus. The red box shows the sampling location with an area of 0.5 ha 
The calculation of leaf damage level used following formula:

$$
\mathrm{P}=\frac{\mathrm{a}}{\mathrm{N}} \times 100 \%
$$

Where, $\mathrm{P}$ is the level of leaf damage (\%), ' $\mathrm{a}$ ' is the number of damaged leaves by herbivorous insects and $\mathrm{N}$ is the total number of leaves (Moekasan et al. 2012).

To measure damaged leaf area due to herbivory activities, leaf pictures were taken for all leaves on the branches of each sampled plant. Measurement of leaf morphometry was done by scanning the leaf area and then processed using SigmaScan 4 software (Systat Software, Inc., San Jose, California USA) to obtain the length and width of the leaves (without stems) for both intact leaves and leaves damaged by herbivores. For herbivory measurements, the leaves were differentiated by age (i.e. for tree habitus was represented old leaves and for sapling was represented by young leaves) and leaf conditions (i.e. intact or damaged). The category of leaf damage was determined by the presence of herbivore marks, indicated by the loss of some leaf area due to bite or perforation of herbivorous insects. The analysis of SigmaScan 4 resulted in the area of lost or damaged leaves. The percentage of herbivory was calculated as follows:

$$
\frac{(\mathrm{PLA}-\mathrm{ALA})}{\mathrm{PLA}} \times 100 \%=\% \text { Herbivory }
$$

Where:

PLA: imaginary leaf area

ALA: remaining leaf area

Estimation of leaf area eaten by herbivores was obtained from the difference in imaginary leaf area (PLA) with the remaining damaged leaf area (ALA) (Khusna 2008). The percentage obtained was then classified based on the percentage of lost leaf area. Cooke et al. (1984) in Septyaningsih et al. (2014) divided the herbivory level into eight classes of damage as follows: (i) $<2.5 \%$, (ii) 2.5 $5.0 \%$, (iii) $5.1-10.0 \%$, (iv) $10.1-20.0 \%$, (v) $20.1-40.0 \%$, (vi) $40.1-60.0 \%$, (vii) $60.1-80.0 \%$, (viii) $>80 \%$.

\section{Leaf nutrient quality: leaf chemical characters}

Analysis of leaf nutrient quality test was carried out monthly to determine total nitrogen, phosphorus, potassium, and water content in plant tissues. Tannin test was carried out at the end of the study. A total of 25 leaves was collected randomly from the sampling site, then they were oven-dried at $70^{\circ} \mathrm{C}$ until the weight is constant, and were ground for chemical analysis. The total $\mathrm{N}$ was determined using Nitrogen Kjeltec unit, while other elements such as total $\mathrm{P}, \mathrm{K}$ (potassium) were determined using Microwave Digestion and Inductively Coupled Plasma Mass Spectrometry (ICP-MS). Water content was determined using oven. Total tannin assay was determined using Ultraviolet-Visible Spectrophotometry. All nutrient content was expressed as percentage of dry weight of the samples.

\section{Diversity and abundance of herbivorous insects}

Following parameters were analyzed, including species richness (number of species) of herbivorous insects, number of individuals (abundance), biodiversity indexes in term of Shannon-Wiener Diversity and Evenness Index (Magurran 2004). The Shannon-Wiener biodiversity index was calculated to determine the diversity of herbivorous insect species in each type of habitat/mangrove using the following formula:

$$
H^{\prime}=-\sum p i \ln p i
$$

Where:

$H^{\prime}$ : Shannon-Wiener's species diversity index $p i$ : Number of individual species of $\mathrm{i}$

\section{Correlation between leaf damage, herbivory level, and leaf nutrient quality}

Difference in leaf damage level and nutrient level (nitrogen total, phosphorus, potassium, and water content) in different plant habitus (sapling and tree) was analyzed using One-way ANOVA. Pearson correlation analysis was conducted to determine the relationship between nutrient contents in leaves and the leaf damage level, and the percentage of herbivory. All calculations were performed using IBM SPSS Statistics software version 22.0.

\section{RESULTS AND DISCUSSION}

\section{Herbivorous insect assemblages at ITS Campus mangrove area}

In general, observations from September to November 2017 showed that herbivorous insects found at mangrove area of the ITS Campus were only less than $20 \%$ of total insects encountered. The mangrove area at ITS Campus tends to be occupied by predator insects with relative abundance of $62.31 \%$, compared to $12.56 \%$ of herbivorous insects. Sixteen herbivore species from five orders, i.e., the Lepidoptera, Coleoptera, Diptera, Hemiptera, and Hymenoptera, were collected from Rhizophora stylosa at ITS Campus mangrove area. The Shannon-Wiener Diversity Index calculation indicates that the level of insect diversity at the mangrove area of ITS Campus is moderate $\left(H^{\prime}=1.5\right)$. Proximity aquaculture and agriculture activities are likely responsible for the moderate abundance and diversity of herbivorous insects, especially in Rhizophora.

The composition of herbivorous insects showed that they are evenly distributed, especially for seven species with the highest number of individuals (Figure 2). At the mangrove area of ITS Campus, groups of pierid butterflies, hemipteran bugs, nymphalid butterflies and coccinellid beetles, such as Delias periboea, Euthochthagaleator, Metcalfa sp., Neptis hylas, and Harmonia axyridis dominate herbivorous insects. Several groups of herbivorous insects are known as chewing herbivores/leaf cutters, such as Pieridae larvae, Nymphalidae, and Coccinellidae beetles. 


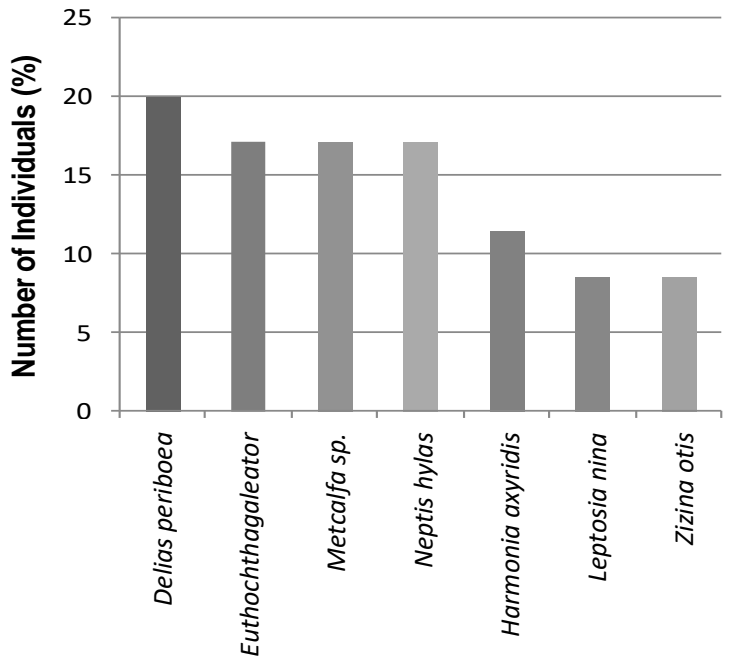

Figure 2. The composition of the seven herbivorous insect species with the highest number of individuals found in the mangrove area of ITS Campus, sapling and tree of $R$. stylosa at the mangrove area of ITS Campus, Surabaya, Indonesia

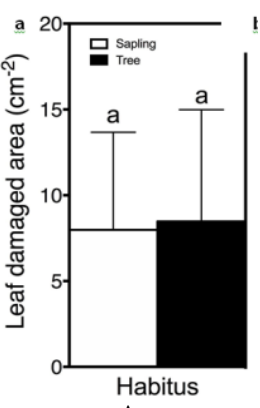

A

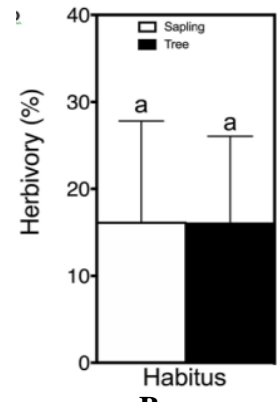

B

Figure 3. The impacts of herbivorous insects on the sapling and tree of R. stylosa at the mangrove area of ITS Campus, Surabaya, Indonesia: A. The proportion of damaged leaf area (\%); B. The percentage of herbivory. The same letter indicates not significantly different at $p>0.05$

\section{Herbivory levels: mangrove leaf damage}

Observation on leaf damage showed that there was no significant difference in the vulnerability of mangrove leaf damage, particularly in Rhizophora in the mangrove area of ITS Campus (Figure 3).

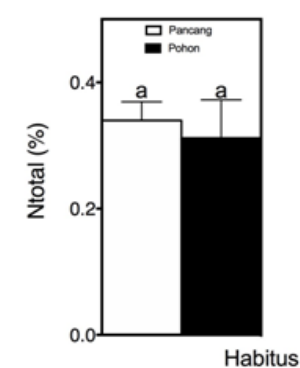

A

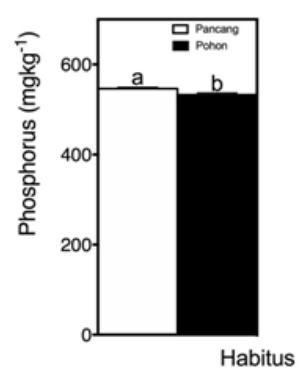

B

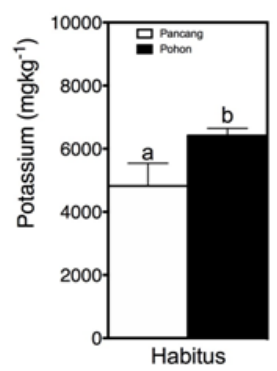

C

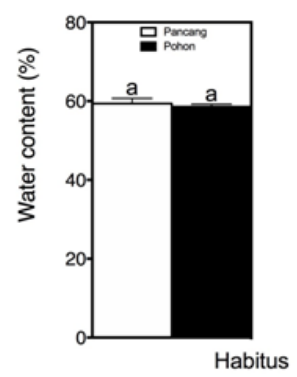

D

Figure 4. Nutrient content in the leaf of $R$. stylosa between sapling and tree habitus at the mangrove area of ITS Campus, Surabaya, Indonesia: A. Total nitrogen (\%); B. Total phosphorus (mg/kg); C. Potassium (K) mg/kg; D. Relative leaf water content (\%). The same letter indicates not significantly different at $p>0.05$ 
Table 1. Total tannin content (phenolics in $\mathrm{mg}$ GAE/g) in the leaves of $R$. stylosa between sapling and tree at the mangrove area of ITS Campus

\begin{tabular}{cc}
\hline Habitus & $\begin{array}{c}\text { Total tannin (Phenolics) } \\
(\mathbf{m g} \text { GAE } / \mathbf{g} \pm \text { SD) }\end{array}$ \\
\hline Sapling & $52.57 \pm 4.13$ \\
Tree & $41.38 \pm 2.19$ \\
\hline
\end{tabular}

Table 2. Results of statistical analysis to examine correlation between nutrient content in leaf and leaf damage at the mangrove area of ITS Campus

\begin{tabular}{lll}
\hline \multicolumn{1}{c}{ Variables to correlate } & \multicolumn{2}{c}{ Habitus } \\
\cline { 2 - 3 } & \multicolumn{1}{c}{ Sapling } & \multicolumn{1}{c}{ Tree } \\
\hline Leaf area damaged vs\% Herbivory & $r=0.753^{* *}$ & $r=0.975^{* *}$ \\
& $p-0.001$ & $p-0.001$ \\
Leaf area damaged vs Total N & $r=-0.942$ & $r=0.609$ \\
& $p-0.219$ & $p-0.583$ \\
Leaf area damaged vs Total P & $r=0.999^{*}$ & $r=-0.462$ \\
& $p-0.034$ & $p-0.694$ \\
Leaf area damaged vs K (potassium) & $r=-0.742$ & $r=0.842$ \\
& $p-0.467$ & $p-0.363$ \\
Leaf area damaged vs water content & $r=0.200$ & $r=-0.062$ \\
& $p-0.871$ & $p-0.961$ \\
\hline
\end{tabular}

Note: *significant at $p<0.05, * *$ significant at $p<0.01$

\section{Discussion}

At the mangrove area of ITS Campus, the abundance of herbivorous insects was less than $20 \%$ of the total individual insects found, as well as having a moderate level of diversity $\left(\mathrm{H}^{\prime}=1.576\right)$. The assemblage of 16 species of herbivorous insect recorded at ITS Campus mangrove area is relatively small compared to those recorded from other tropical mangrove forests. Murphy (1990) reported that there are 102 species of herbivorous insects from Singapore mangrove, while Rau and Murphy (1990) reported 37 species from Thailand mangroves. Veenakumari et al. (1997) recorded 128 herbivorous species from the Andaman and Nicobar Islands of India. More recently, Burrows (2003) recorded a total of 61 species of herbivorous insect from Avicennia marina (31 species) and Rhizophora stylosa (34 species) from Queensland, Australia.

This study recorded hemipteran bugs dan Lepidoptera larvae dominate insect assemblages in Rhizophora mangrove. The lower species diversity recorded in all locations is likely caused by bias in sampling method toward less mobile insects, especially Lepidoptera larvae. Veenakumari et al. (1997) reported Lepidoptera constituted over half the number of herbivorous species in the mangals of the Andaman and Nicobar islands. Burrows (2003) showed a higher proportion of Lepidoptera and Hemiptera, but a lower proportion of Diptera and Coleoptera. Also, Burrows reported that Lepidoptera and Hemiptera were the co-dominant groups, while Diptera was also common, but Coleoptera was poorly represented in the mangrove on Queensland, Australia.

The results on the composition of herbivorous insects indicate that the surrounding environment of mangroves, such as agricultural lands, also influences the composition of herbivorous insects found at the mangrove area of ITS Campus. At this area, species of pierid butterflies, hemipteran bugs, nymphalid butterflies and coccinellid beetles dominate herbivorous insects. Pierid butterflies such as Delias sp. are found mostly in the canopy of trees, especially in urban areas, parks, and mangroves (Khew 2010). Some Delias species, such as adult butterflies of $D$. aestiva are found mainly in coastal swamps and mangroves paperbark (Braby 2000), while D. mysis is associated with riparian forest and lowland rainforest (Davenport and van Mastrigt 2009). Delias aestiva has an obligatory association with mangroves in which it requires mature foliage of Euphorbiaceae, Excoecaria ovalis Endl (Braby 2012). Leaf-footed bugs Euthochtha is sap-sucking insects and pest in cucurbits. Mead (2003) reported that species of Euthochtha cause defoliation of cultivated host plants (e.g., a lesser extent of fruits) and wild host plants (e.g., composites, grasses, sedges, nettles). Damage to leaves caused by Euthochtha is indicated by young leaves become droopy, withered, and brownish, while blossoms become malformed. The adults of Metcalfa sp. feed on plant sap and usually cause serious damage to field crops, orchard and forest trees (Mead 2004). Nymphalidae species, Neptis sp. in early stages feed on leaves of various plant species. In Singapore, plants from Leguminosae family have been recorded as larval hosts of Neptis (Khew 2010). Coccinellidae beetles such as Harmonia axyridis and Calliphara excellent are known as polyphagous of various plants and minor pests on vegetable and other cultivated crops. Calliphara sp. is a species of beetle known to live in mangroves, especially Excoecaria agallocha, and feeds on growing stages of saplings (Koch 2003; Ng \& Sivasothi 1999).

In general, nearly all inflicted damages on mangrove green leaves caused middle and marginal damages on the lamina. The herbivory level on $R$. stylosa leaves collected from trees was slightly higher than that of saplings. This indicates that tree habitus tends to be more vulnerable to herbivory in the form of leaf damage by insects compared to saplings. However, the results of statistical analysis showed non-significant differences in leaf damaged area and herbivory percentage between saplings and trees. More samples and sampling periods are suggested to see a clearer trend in leaf damage between sapling and trees. Nutrient inputs to rivers and coastal waters are thought to affect the vulnerability of plants to herbivory by herbivorous insects. According to Turner et al. (2009) and Feller et al. (2017), mangrove forests in the tropics face the problem of increasing runoff of nutrients in coastal wetlands, which already face increasing nutrient loading from human activities, such as agriculture and aquaculture. Moreover, for decades mangroves have been proposed as location for sewage and aquaculture effluent treatment, although assessment of long-term consequences of nutrient enrichment for mangrove ecosystems is lacking (Clough et al. 1983; Lovelock et al. 2009). The effects of nitrogen fertilization on population dynamics and natural control of herbivorous insects were studied in an irrigated rice area by de Kraker et al. (2000). They found that the average density 
of leaf folder larvae at the highest nitrogen level was eight times more than that at the zero nitrogen level, while the damaged leaves ranged from $5 \%$ to $35 \%$. In further study, Feller et al. (2017) reported that $\mathrm{N}$-fertilized trees had greater folivory, although fertilization did not significantly affect herbivory or herbivore diversity. The study also found that added nutrients increase growth and alter leaf traits, which vary by feeding guild and location but are not correlated with latitude.

Based on plant habitus, leaf damage level in tree was slightly higher than that of sapling, although it is nonsignificantly different. Burrows (2003) suggested that twothirds to three-quarters of the consumptive leaf area damaged by herbivorous insects have occurred on young leaves than older leaves. In general, age-based herbivory that included data from 73 tropical plant species from the Coley and Aide's study (1991) found that 40-75\% of total lifetime herbivory occurred on young developing leaves. Furthermore, Burrows (2003) explained that mangrove leaves change substantially in their physical and chemical composition as they age. These attributes are likely to affect their palatability and resistance to herbivory. Therefore it can be seen that young leaves on sapling habitus are more vulnerable to herbivory than older leaves.

The herbivory levels on $R$. stylosa recorded in this study ranged from $85.677 \%$ to 89.847 on average, revealing that $R$. stylosa foliage is highly susceptible to herbivore attack. Burrows (2003) reported 2.11-4.23\% of leaf area damage on $R$. stylosa and 5.90-8.45\% of leaf area damage on A. marina in Queensland, Australia. Tong et al. (2006) recorded 1.6 to $6.5 \%$ herbivory levels on Kandelia obovata in Hongkong with the highest herbivory level of $3.8 \%$ was recorded in summer (August). Also, leaves collected from Hongkong contained significantly higher contents of total nitrogen in two different locations in a few months (ranged 1.43 to $2.11 \%$ ). According to Tong et al. (2006), nutritional factors of nitrogen enrichment, both naturally and artificially, have a significant relationship with the level of leaf damage by herbivorous insects.

In this study, leaves collected from saplings have nonsignificantly higher $(p-0.12)$ in total nitrogen content (mean: $0.34 \%)$ than that of trees $(0.31 \%)$. However, total phosphorous content in sapling leaves showed significantly higher than that of trees. In terms of plant habitus, concentrations of total phosphorous in younger mangroves (sapling) were about $546,26 \mathrm{mg} / \mathrm{kg}$ higher than that of tree $(532.59 \mathrm{mg} / \mathrm{kg})$. According to Schoonhoven et al. (1998), differences in herbivory level on leaves are often attributed to differences in nutrient contents, affecting their nutritive value to herbivorous insect. These chemical properties of leaves will vary as they age, with major change will occur as young leaves develop and mature leaves senescence. Tong et al. (2006) reported that young leaves of $K$. obovata have significantly higher concentration of nitrogen content than mature leaves in the summer (August-September). Regarding the level of vulnerability to herbivores, Burrow (2003) explained that most herbivores occurred while the leaves were young. Once past the juvenile phase, $R$. stylosa leaves were rarely attacked. It is assumed that younger habitus has better nutrient quality. Feller et al. (2017) reported that the percentage of Avicennia marina leaf area lost or damaged reaches the highest number (5 to $20 \%$ of the leaf area) as the nutrient content in the leaves, namely $\% \mathrm{~N}$ and $\% \mathrm{P}$, are relatively high. Goncalves-Alvim et al. (2011) found that nitrogen content is negatively correlated with tannin content. When nitrogen limits plant growth, carbohydrates will be accumulated in plant tissues and used for tissue differentiation products, increasing the synthesis of carbon-based secondary metabolites, such as tannins and terpenes. Furthermore, Goncalves-Alvim et al. (2011), found higher percentage of tannins and nitrogen in younger than in mature leaves of Qualea parviflora in Brazilian Cerrado. The synthesis of phenolic compounds such as tannins begins in young leaves and some studies reported increases and decreases of tannins and other phenolic metabolites along with leaf development (Salatino et al. 1993; Goncalves-Alvim et al. 2011).

In this study, correlation analysis showed a significant linear relationship between leaf damage level to leaf nitrogen content, where the high level of leaf damage is likely influenced by the high nitrogen content of mangrove leaves. Onuf et al. (1977) recorded that the number of new leaves of red mangroves damage due to the activities of Ecdytolopha sp. was considerably greater in the high- than the low-nutrient (in term of mean percent nitrogen) site in Florida mangrove. More recently, Kathiresan (2003) reported that leaf damage was found to be maximum in Avicennia spp., and the difference on leaf damage has been attributed to leaf chemistry, especially tannin content. Tannin, as a deterrent against herbivores, is assumed to reduce palatability and digestibility of herbivorous insects.

In term of adaptation to herbivory, leaves of mangrove tree tend to be more vulnerable to herbivorous insects than that of sapling. There was significant difference between tree and sapling in the total $\mathrm{P}$, potassium $(\mathrm{K})$ and leaf water content, but was not significant in the total $\mathrm{N}$ leaf content. Leaf damage is assumed to be related to the significant differences in leaf phosphorous content.

Although there are differences in leaf chemical characteristics in the form of nutrient quality and leaf water content, the results of Pearson Correlation analysis generally show that there is no correlation between leaf damage due to herbivorous insects and leaf nutrient levels. It indicates that no influence of leaf nutrient level with increased vulnerability of mangroves to herbivorous insects, especially in $R$. stylosa.

In assessing the vulnerability of mangroves to herbivorous insects, it is better to use various methods of sampling to obtain representative herbivorous insect communities at the mangrove area of ITS Campus. Also, deterrent leaf chemical (i.e., tannin, crude fiber, chloride, potassium) tests should be done to complement leaf nutrient test (total nitrogen, phosphorus, potassium, and water content) as this study conducted. Similarly, testing the leaf nutrient content should be expanded to various ages and mangrove species. Also, we suggest to observe the availability of nutrients and secondary metabolites in different mangrove habitats. 


\section{ACKNOWLEDGEMENTS}

We thank the farmers at the ITS Campus, Surabaya, Indonesia involved in this research for their supports. We are also grateful to Sri Fatmawati, Ph.D. (Laboratory of Natural Products and Synthesis Chemistry, ITS) for her comments and for total tannin analyses. Financial support was provided by ITS Research and Community Service Institutions (LPPM ITS). We also thank Harfianto Nurogo Sakti, Rizqy Noor Abdurrahman and Muhammad Afif Berlian for their help with data collection and documentation, and all those who have helped the authors in completing this research.

\section{REFERENCES}

Alongi DM. 2002. Present state and future of the world's mangrove forests. Environ Conserv 29: 331-349.

BSN. 2011. Survei dan pemetaan mangrove. SNI 7717: 2011. Badan Standardisasi Nasional, Jakarta. [Indonesia]

Bengen DG, Dutton IM. 2003. Interactions between mangroves and fisheries in Indonesia. In: Northcote TG, Hartman GF (eds) Fishes and Forestry - Worldwide Watershed Interactions and Management Blackwell Scientific, New Jersey, USA.

Braby MF. 2000. Butterflies of Australia. Their Identification, Biology and Distribution. CSIRO Publishing, Melbourne, Australia.

Braby MF. 2012. The taxonomy and ecology of Delias aestiva Butler, 1897 stat. rev. (Lepidoptera: Pieridae), a unique mangrove specialis of Euphorbiaceae from northern Australia. Biol J Linn Soc 107 (3): 697-720.

Burrows DW. 2003. The Role of Insect Leaf Herbivory on The Mangroves Avicennia marina and Rhizophora stylosa. [Thesis]. School of Tropical Biology. James Cook University, Townsville, Campbell JW, Hanula JL. 2007. Efficiency of Malaise traps and colored pan traps for collecting flower-visiting insects from three forested ecosystems. J Insect Conserv 11: 399-408.

Cannicci S, Burrows D, Fratini S, Smith TJ, III, Offenberg J, DahdouhGuebas F. 2008. Faunal impact on vegetation structure and ecosystem function in mangrove forests: A review. Aquat Bot 89: 186-200.

Clough BF, Boto KG, Attiwill PM. 1983. Mangrove and sewage: a reevaluation. In: Teas HJ (eds) Biology and Ecology of Mangroves. Tasks for Vegetation Science Series, Vol. 8. Dr. W Junk Publishers, Lancaster, UK.

Coley PD, Aide TM. 1991. Comparison of herbivory and plant defenses in temperate and tropical broad-leaved forest. In: Price PW, Lewinsohn TM, Fernandes GW, Benson WW (eds) Plant-Animal Interaction: Evolutionary Ecology in Tropical and Temperate Regions. John Wiley and Sons, Inc., New York.

Cooke FP, Brown JP, Mole S. 1984. Herbivore enzyme inhibitor, nitrogen and leaf structure of young and mature leaves in a tropical forest. Biotropica 16 (4):257-263.

Davenport C, van Mastrigt HJG. 2009. Revision of Delias mysis (Fabricius, 1775) and closely related species (Lepidoptera: Pieridae) Suara Serangga Papua 3: 15-31. [Indonesia]

de Kraker J, Rabbinge R, Huis AV, Lenteren JCV, Heong KL. 2000. Impact of nitrogenous-fertilization on the population dynamics and natural control of rice leaf folder (Lep: Pyralidae). Int J Pest Manag 46: $225-235$.

Feller IC, Chamberlain AH, Piou C, Chapman S, Lovelock CE. 2013 Latitudinal patterns of herbivory in mangrove forests: Consequences of nutrient enrichment. Ecosystems 16: 1203-1215.

Feller IC, Ball MC, Ellis JI, Lovelock CE, Reef R. 2017. Interactive effects of climate and nutrient enrichment on patterns of herbivory by different feeding guilds in mangrove forests. Global Ecol Biogeogr: $1-13$

Goncalves-Alvim SJ, Lana TC, Ranieri BD, Fernandes GW. 2011. Test of hypotheses about herbivory and chemical defenses of Qualea parviflora (Vochysiaceae) in Brazilian Cerrado. Rev Bras Bot 34 (2): 223-230
Green JL, Joe C. 1990. A Systematic Approach to Diagnosing Plant Damage. Ornamentals Northwest Arch 13 (6): 2-24.

Grundy D. 2010. GMS moth tips 2: Identification of Macro-moth Families and Sub-families. Garden Moth Scheme. Staffordshire Ecological Record, Staffordshire, UK.

Kathiresan K. 2003. Insect folivory. Indian J Mar Sci 32 (3): 237-239.

Khew SK. 2010. A Field Guide to The Butterflies of Singapore. Ink on Paper Communications Pte Ltd, Singapore.

Khusna E. 2008. Studi morfometri dan tingkat herbivori daun mangrove Rhizophora mucronata Lamk dan Avicennia marina (Forsk) Vierh di Kecamatan Legon Kulon dan Pusakanegara, Subang, Jawa Barat. [Hon. Thesis]. FPIK Universitas Diponegoro, Semarang. [Indonesian]

Koch RL. 2003. The multicolored Asian lady beetle, Harmonia axyridis: A review of its biology, uses in biological control, and non-target impacts. J Insect Sci 3: 32

Labandeira CC, Peter W, Kirk RJ, Finnegan M. 2007. Guide to Insect (and Other) Damage Types on Compressed Plant Fossils. Smithsonian Institution, Washington, DC

Lloret J, Marín A, Marín-Guirao L. 2008. Is coastal lagoon eutrophication likely to be aggravated by global climate change? Estuar Coast Shelf Sci 78: 403-412.

Lovelock CE, Ball MC, Martin KC, Feller IC. 2009. Nutrient enrichment increases mortality of mangroves. PLoS ONE 4 (5): e5600. DOI: 10.1371/journal.pone.0005600.

Magurran AE. 2004. Measuring Biological Diversity. Blackwell Publishing, Oxford.

Mead FW. 2003. Featured Creatures: Coreid Bug, Leaf Footed Bug. DPI Entomology Circular 222. Florida Department of Agriculture and Consumer Services, Division of Plant Industry, Miami, FL.

Mead FW. 2004. Featured Creatures: Flatid Planthopper. DPI Entomology Circular 85. Florida Department of Agriculture and Consumer Services, Division of Plant Industry, Miami, FL.

Moekasan TK, Basuki RS, Prabaningrum L. 2012. Penerapan ambang pengendalian organisme pengganggu tumbuhan pada budidaya bawang marah dalam upaya mengurangi penggunaan pestisida. J Hort 22 (1): 47-56. [Indonesian]

Murphy DH. 1990. The natural history of insect herbivory on mangrove trees in and near Singapore. Raffles Bull Zool 38: 119-204.

Ng PKL, Sivasothi N. 1999. Shield/Stink bug (Calliphara nobilis). A Guide to the Mangroves of Singapore II (Animal Diversity). Singapore Science Centre, Singapore.

Ong JE, Khoon GW. 2003. Carbon fixation in mangrove ecosystem and carbon credits. Theme B from the East Asian Sea Congress: Essential Cross-Sectoral Processes and Approaches to Achieving Sustainable Development Conference Bulletin. Issue 2, 11 July 2012.

Onuf CP, Teal JM, Valiela I. 1977. Interactions of nutrients, plant growth and herbivory in a mangrove ecosystem. Ecology 58 (3): 514-526.

Rau MT, Murphy DH. 1990. Herbivore attack on mangrove plants at Ranong. Mangrove Ecosyst Occas Pap 7: 25-36.

Salatino A, Kraus JE, Salatino MFL. 1993. Contents of tannins and their histological localization in young and adult parts of Struthanthus vulgaris Mart. (Loranthaceae). Ann Bot 72: 409-414.

Setyawan AD, Kusumo W. 2006. Pemanfaatan langsung ekosistem mangrove di Jawa Tengah dan penggunaan lahan di sekitarnya; kerusakan dan upaya restorasinya. Biodiversitas 7 (3): 282-291. [Indonesian]

Septyaningsih E, Ardli ER, Widyastuti A. 2014. Studi morfometri dan tingkat herbivori daun mangrove di segara Anakan Cilacap. Scripta Biologica 1 (2): 137-140. [Indonesian]

Schoonhoven LM, Jermy T, van Loon JJA. 1998. Insect-Plant Biology: From Physiology to Evolution. Chapman and Hall, Cambridge.

Tong YF, Lee SY, Morton B. 2006. The herbivore assemblage, herbivory and leaf chemistry of the mangrove Kandelia obovata in two contrasting forests in Hong Kong. Wetland Ecol Manag 14: 39-52.

Turner RE, Howes BL, Teal JM, Milan CS, Swenson EM, GoehringerToner DD. 2009. Salt marshes and eutrophication: An unsustainable outcome. Limnol Oceanogr 54: 1634-642.

Wantasen AS. 2013. Kondisi kualitas perairan dan substrat dasar sebagai faktor pendukung aktivitas pertumbuhan mangrove di Pantai Pesisir Desa Basaan I, Kabupaten Minahasa Tenggara. J Ilmiah Platax 1 (4): 204-209. [Indonesian]

Veenakumari K, Mohanraj P, Bandyopadhyay AK. 1997. Insect herbivores and their natural enemies in the mangals of the Andaman and Nicobar islands. J Nat Hist 31 (7): 1105-1126.

Voshell Jr JR. 2002. A Guide to Freshwater Invertebrates of North America. Mc Donald \& Woodward Publishing Co., Blacksburg, VA. 
